KfK 3223

Oktober 1981

\title{
Enhancement of Heat Transfer between Two Horizontal Liquid Layers by Gas Injection at the Bottom
}

\author{
H. Werle \\ Institut für Neutronenphysik und Reaktortechnik \\ Projekt Nukleare Sicherheit
}

\section{Kernforschungszentrum Karlsruhe}





\section{KERNFORSCHUNGSZENTRUM KARंLSRUHE}

Institut für Neutronenphysik und Reaktortechnik

Projekt Nukleare Sicherheit

KfK 3223

Enhancement of Heat Transfer between Two Horizontal Liquid Layers by Gas Injection at the Bottom

H. Werle

Kernforschungszentrum Karlsruhe GmbH, Karlsruhe 
Als Manuskript vervielfältigt

Für diesen Bericht behalten wir uns alle Rechte vor

Kernforschungszentrum Karlsruhe GmbH

ISSN 0303-4003 
Enhancement of Heat Transfer between Two Horizontal Liquid

Layers by Gas Injection at the Bottom

\section{Summary}

In connection with investigations concerning the core melt concrete interaction the enhancement of heat transfer between two horizontal liquid layers by gas injection has been studied using two systems - oil over water and oil over wood metal - with very different density ratios. For the largest gas injection rate (superficial gas velocity $0.63 \mathrm{~cm} / \mathrm{s}$ ) the heat transfer coefficient is increased by nearly a factor 400 for oil over water and by about a factor of ten for oil over wood metal. In the core melt - concrete interaction the superficial gas velocities might be even higher, therefore the gas - induced enhancement of interfacial heat transfer should be taken into account.

Erhöhung des Wärmeübergangs zwischen zwei horizontalen Flüssigkeitsschichten durch Gasinjektion am Boden

\section{Zusammenfassung}

In Zusammenhang mit Untersuchungen zur Kernschmelze-Beton-Wechselwirkung wurde die durch Gasinjektion hervorgerufene Erhöhung des Wärmeübergangs zwischen zwei horizontalen Flüssigkeitsschichten an zwei Systemen - $\varnothing 1$ über Wasser und 01 ober Wood-Metall - mit sehr unterschiedlichen Dichteverhältnissen untersucht.

Bei der größten Gasinjektionsrate (" superficial gas velocity "0.63 cm/s) erhöht sich der Wärmeübergangskoeffizient bei öl iber Wasser um fast den Faktor 400 und bei öl über Wood-Metall um zehn. Bei der KernschmelzeBeton-Wechselwirkung können noch höhere Gasinjektionsraten auftreten. Deshalb sollte die dadurch hervorgerufene Erhöhung des Wärmeübergangs über die Grenzfläche berücksichtigt werden. 
INTRODUCTIION

Experimental investigations of molten core debris- concrete interactions show that contact between melt and concrete is marked by vigorous gas evolution /1/. Pool behaviour and heat transfer is then governed mainly by the stirring action of the percolating gases and natural convection plays only a minor role.

A pool of molten core debris normally will consist of two liquid phases, an oxydic and a metallic. For an estimation of the growth rate of the pool into the concrete, heat transfer at the pool boundaries and in addition, heat transfer between the two liquid phases has to be known. Heat transfer at the pool boundaries has been studied with simulant materials either by injection of gases at the boundaries of convection cells /2-4/ or by observing the penetration of a liquid pool into decomposing, gas evoluting solids $/ 5,6 /$. These experiments show that the gas will vigorously mix the pool and compared to pure natural convection this leads to

- a flattening of the temperature distribution and a decrease of the temperature difference between the pool and the boundaries and to

- remarkable chenges of the heat tramsfer rates at the pool boundaries.

The aim of the present study was to investigate the influence of gas injection on the heat transfer between two horizontal immiscible liquid layers. The results may be used in integral codes like WECHSL /6/ or CORCON / 7/ to describe the complex melt-concrete interaction.

In the experiments the lower, higher density layer is heated. Therefore the experiments simulate the initial (oxide is more dense and has a higher power density than metal) or the final phase (because of dilution with concrete oxide is less dense and has a lower power density than metal) of the melt-concrete interaction. Bottom heating is used, but it is expected that the local distribution of the heat sources will not strongly influence interfacial heat transfer. 
Two systems - silicone oil (density $0.91 \mathrm{~g} / \mathrm{cm}^{3}$ ) over water and silicone oil over wood metal (density $9.5 \mathrm{~g} / \mathrm{cm}^{3}$ ) - were investigated to study in addition the influence of the density ratio.

\section{EXPERIMENTAL APPARATUS AND PROCEDURE}

A schematic diagram of the apparatus is shown in Fig. 1. The doublelayer, liquid system is contained is a cylindrical cell. The bottom consists of an electrically heated, porous plate. At the surface a helical heat exchanger tube is immersed in the liquid. The boundaries are essentially adiabatic. The volumetric gas flow rate $V$ is measured with a flow meter. The electical power $P_{e l}$ is determined with a wattmeter and the thermal power $P_{t h}$ of the heat exchanger (HX) by the rate (flow meter) and the temperature rise (thermocouples TC) of the cooling water. To determine the vertical temperature distribution $\mathrm{T}(\mathrm{z})$ a series of thermocouples (Type J, sheath diameter $1 \mathrm{~mm}$ ) were located inside the liquid system equally spaced (10mm) near the axis of the cell.

For the system oil over water the cell consisted of a glass vessel (inner diameter $13 \mathrm{~cm}$, wall thickness $3 \mathrm{~mm}$ ). The bottom (area $133 \mathrm{~cm}^{2}$ ) consisted of a $14 \mathrm{~mm}$ thick layer of glass balls (4mm diameter) on top of a porous glass plate. In this layer a helical heating coil was inserted. Air was used in this case. Details of the experimental arrangement are shown in Fig. 2 .

For the system oil over Wood metal the glass vessel was replaced by a plexiglass vessel (inner diameter $14 \mathrm{~cm}$, wäll thickness 10mm) to reduce the heat losses (Fig. 6). In addition the bottom used previously was replaced by an electrically heated copper plate (area $154 \mathrm{~cm}^{2}$ ) in which a square pattern (distance 10mm) of $1 \mathrm{~mm}$ diameter holes were drilled for gas injection. Nitrogen was used to avoid oxydation of the hot Wood metal. Details of the two slightly different arrangements used are shown in Fig.3. 
The experiments were performed such that in one run the heat flux was kept constant and the gas injection rate was varied parametrically (oil over water) or vice versa (oil over wood metal). After reaching equllibrium the vertical temperature distribution $T(z)$ was registered, which is than used to infere the difference between the bulk temperatures of the two layers $\Delta T$ as a function of the heat flux $j=P_{\text {el }} \mid A$ and of the superficial gas velocity $v=V / A$ ( $A$ is the bottom area). For the systen oil over water the temperature at the heat exchanger inlet was $10^{\circ} \mathrm{C}$. For the system oil over wood metal this temperature had to be raised with increasing gas flow to avoid solidification of the Wood metal.

The Wood metal (type CR35; 5OBi-25Pb-12.5Sn-12.5Cd) " has a density of $9.5 \mathrm{~g} / \mathrm{cm}^{3}$ and a melting point between 69 and $71^{\circ} \mathrm{C}$. Material properties for the silicone oil $\mathrm{Ak} 5^{* *}$ used are given in Tab. 1.

\section{RESULTS}

In explanatoring experiments, the influence of the gas bubble diameter has been investigated by using different porous bottoms. The results for oil over water shown in Fig. 4 demonstrate, that variations of the bubble diameter between about 1 and $4 \mathrm{~mm}$ do not markedly influence the interfacial temperature difference $\Delta T$.

In Fig. 5 the electrically $\mathrm{P}_{\text {el }}$ and thermally $\mathrm{P}_{\text {th }}$ measured powers are compared. ( The different data sets are identified by numbers to facilitate cross-correlation with the original data). For the system oil over water $P_{\text {th }}$ is generally by about $7 \%$ lower than $P_{e l}$ and this is attributed to the heat losses at the boundaries and to heat-up of injected gas $(\leq 5 \mathrm{~W})$. Although the heat losses are certainly much lower for the system oil over Wood metal, contained within thick plexiglass walls, $\mathrm{P}_{\text {th }}$ is generally much lower than $\mathrm{P}_{\text {el }}$ (about 30\%). This large discrepancy

\footnotetext{
* DODUCO, Pforzheim, W. Germany

* Wacker-Chemie, München, W. Germany
} 
is mainly attributed to systematic errors in $P_{\text {th }}$ (about $\pm 25 \mathrm{~W}$ ) due to the small temperature rise of the heat exchanger cooling water (only $4^{\circ} \mathrm{C}$ for the maximum power level). The electically measured power is assumed to be more reliable - the error is estimated to be below $5 \%$ - and therefore $P_{e l}$ is used for evaluation.

In the case oil over water gas bubbles with diameters between 1 and about $4 \mathrm{~mm}$ were released more or less informly distributed over the bottom area. The gas bubbles cause an irragular, wavy movement of the interface and the surface and in addition, a complex mass transfer across the interface. Already at moderate values of the superficial gas velocity, small water droplets are carried along with the bubbles into the oil layer. They coalesce within or at the surface of the oil layer and descend as large droplets to the interface. Here they stay for some time before they recombine with the water layer. Both the movement of the interface and the deposition of water droplets there cause the development of a mixing layer which increases in thickness with increasing $v$. Above $v=0.4 \mathrm{~cm} / \mathrm{s}$, also transport of oil into the water layer is observed and the layered system changes to a more or less homogeneous mixture.

For the system oil over Wood metal the behaviour is quite different (Fig. 6): Although the quite large bubbles ( $10 \mathrm{~mm}$ diameter) cause again an irregular, wavy movement of the interface and the surface, even at the highest gas velocities ( $v=0.63 \mathrm{~cm} / \mathrm{s}$ ) no mixing between the two layers is observed. Although nitrogen was used after some time the Wood metal was partly oxydized. The oxydation products tend to block the gas injection channels, leading to nonuniform gas injection in some cases.

The measured vertical temperature distribution $T(z)$ is shown in Fig.7. With increasing gas velocity $v$ the temperature distribution flattens until for the highest values of $v$, at least for the system oil over water, the liquid system is nearly isothermal. As has been mentioned, for oil over water the inlet temperature at the heat exchanger was always $10^{\circ} \mathrm{C}$. For oil over wood metal the heat exchanger inlet 
temperature had to be raised with increasing gas velocity to keep the wood metal molten (melting point $70^{\circ} \mathrm{C}$ ). This is reflected in the temperature distributions.

Except for wood metal the bulk of the liquid layers is very nearly isothermal. For the system oil over water the interfacial temperature difference $\Delta \mathrm{T}=\mathrm{T}_{\text {high }}-\mathrm{T}_{\text {low }}$ was determined by taking for $\mathrm{T}_{\text {low }}$ the average of thermocouples 5 and 6 and for $T_{\text {high }}$ thermocouple 2 (Fig. 7). For the system oil over wood metal $\mathrm{T}_{\text {low }}$ was calculated from the average of thermocouples 4,5 and 6 . To determine $T_{\text {high' }}$ because of the remarkable temperature gradient in the wood metal layer, the values of thermocouples 1 and 2 have been extrapolated for the position of the interface. The residual systematic error in $\Delta T$ after calibration of the thermocouples is estimated to be $\pm 0.2{ }^{\circ} \mathrm{C}$. This is the main contribution to the error in the evaluated heat transfer coefficients (Fig. 9).

EVALUATION

For a single liquid layer heated at the bottom and cooled at the top, the heat flux is according to /9/

$$
j_{\text {single }}=h_{\text {single }}^{*}\left(\text { matérial properties) } \cdot \Delta \mathrm{T}_{\text {single }}^{4 / 3}\right.
$$

where $\Delta T$ single is the temperature difference between the boundaries. Applying this result to a double layer by assuming that in each layer the temperature profile is symetrical one gets for the interfacial heat flux

$$
j=h^{*} \cdot \Delta T^{4 / 3}
$$

where $\Delta T$ is now the difference between the bulk temperatures of the two layers and $h^{*}$ depends on the material properties of both layers.

Following this relation the experimental data were correlated by

$$
j=h(v) \cdot h^{*} \cdot \Delta T^{4 / 3}
$$


assuming that the gas injection increases the heat flux by a factor $h(v)$, depending only on the superficial gas velocity $v$.

The results are' summarized in Tab. 2 and 3 . The data corresponding to a certain value of $v$ (and different values of $j$ ) are grouped together in main columns. Each main column contains three subcolumns. The first gives the interfacial temperature difference $\Delta T$, the second the quantity $j / \Delta T^{4 / 3}=h_{*}(v) h^{*}$. The values of this subcolumn are averaged to determine $\left(\mathrm{h}(\mathrm{v}) \mathrm{h}^{*}\right)$ av given in the second line from below. The third column contains the quantity $j /\left(h(v) h^{*}\right)$ av which is used to check if the evaluation procedure is appropriate. If this is the case all values $j /\left(h(v) h^{*}\right)$ av should fall on a line corresponding to $\Delta \mathrm{T}^{4 / 3}$. The values $\left(\mathrm{h}(\mathrm{v}) \mathrm{h}^{*}\right)$ av of the second line from below are finally normalized to the value for $v=0$ which gives the $h(v) a v^{-}$ values shown in the last line.

In Fig. 8 the normalized heat fluxes $j /\left(\mathrm{h}(\mathrm{v}) \mathrm{h}^{*}\right)$ av are shown as a function of the interfacial temperature difference $\Delta \mathrm{T}$. The experimental data are quite well fitted by the line corresponding to $\Delta \mathrm{T} 4 / 3$ demonstrating that the relation (3) is an appropriate description of the experimental data.

In Fig.9 finally the heat transfer coefficient $h_{a v}(v)$ (last line of Tab. 3 and 4 ) is shown as a function of the superficial gas velocity. To determine this quantity the individual values corresponding to different heat fluxes but to the same superficial gas velocity have been averaged. The heat transfer coefficient $h_{a v}(v)$ corresponds to the relative interfacial heat flux normalized to that for pure thermal convection.

For the system oil over water the heat flux increases initially quite steeply, with increasing $v$, it then flattens to increase again steeply at about $\mathrm{v}=0.4 \mathrm{~cm} / \mathrm{s}$. This second steep increase is attributed to the beginning of a strong mixing process. The influence of gas injection is very strong leading to a heat flux which is for v=0.63 cm nearly 
a factor 400 higher than the pure thermal convection value. (In a previous evaluation of the oil over water data /10/, especially for large $v$, somewhat higher $h_{a v}(v)$ - values, up to a factor of 1.7 for $v=0.63 \mathrm{~cm} / \mathrm{s}$, have been obtained. The difference comes from the fact that in this reevaluation the results of a calibration of the thermocouples have been taken into account). For the system oil over Wood the influence of gas injection is, as expected, due to the larger density difference, much less than for oil over water. Nevertheless the heat transfer increases steadily with $v$ up to a factor of about ten for $v=0.63 \mathrm{~cm} / \mathrm{s}$. The results of the two data sets $(78 / 12 / 7)$ and $(79 / 1 / 26)$ are shown separately to get an additional idea of the accuracy of the data.

Reimann and stiefel /11/ have fitted the measured heat transfer coefficients by

$$
h_{a v}(v)=1+608\left(\frac{v}{u}\right)\left(\frac{\rho_{h}-\rho_{1}}{\rho_{1}}\right)^{-0.43}
$$

where $u$ is the rising velocity of the gas bubbles and $\rho_{h}$ and $\rho_{l}$ the density of the heavier and the highter liquid respectively. Fig.9 shows that this relation describes the data well as long as there is a distinct interface between the two layers (no strong mixing).

\section{CONCLUSIONS}

Gas injection at the lower boundary increases the interfacial heat flux between two(immiscible) liquid layers drastically. The influence is especially pronounced if the density difference is small. But even for quite large density differences $\left(8.6 \mathrm{~g} / \mathrm{cm}^{3}\right.$ for oil over Wood metal), the heat flux is increased by about a factor of ten for quite moderate superficial gas velocities $(0.63 \mathrm{~cm} / \mathrm{s})$. During the interaction of a core melt with concrete the superficial gas velocities might be appreciable higher (some $10 \mathrm{~cm} / \mathrm{s}$ ). Therefore the effect of enhanced interfacial heat transfer by gas injection has to be taken into account. 


\section{References}

/1/ Powers D.A." Substained molten steel/concrete interactions tests" Proc. Third Post Accident Heat Removal Information Exchange, ANL 1977, ANL-78-10 (1978), p.433

/2/ Fieg G., "Experimental investigations of heat transfer characteristics in liquid layers with internal heat sources," Proc, Int. Meeting Fast Reactor safety and Related Physics, Chicago 1976, CONF-761001 (1976), p.2047

/3/ Abdel-Khalik, S.I, and Felde D.K., " Heat Transfer in volumetrically-heated pools with gas injection at the boundaries", Proc. Third Post Accident Heat Removal Information Exchange, ANL 1977, ANL-78-10 (1978), p.353

/4/ Bergholz R.F. and Bjorge R., "Bubble induced heat transfer in a heat generating liquid layer,"

Proc. Third Post Accident Heat Removal Information Exchange, ANL 1977, ANL-78-10 (1978), p.361

/5/ Dhir V.K., Catton J. and Cho. D., "Heat transfer from a liquid pool to a decomposing solid surface", Proc. Third Post Accident Heat Removal Information Exchange, ANL 1977, ANL-78-10 (1978), p.141

/6/ Alsmeyer H., Barleon L., Koster J., Michael J., Miller V., and Reimann M.," Ein Modell zur Beschreibung der Wechselwirkung einer Kernschmelze mit Beton;" KfK2395 (1977), NUREG/TR-0039(1978)

/7/ Muir J.F., "Molten Core-Concrete Interaction Model Development," Sandia Laboratories Light Water Safety Research Program, Quarterly Report January-March 1978, NUREG/CR-0324,SAND78-1511 (1978), p. 26 
/8/ "Wacker-Silicone, Siliconöle AK", Wacker-Chemie GmbH, München,

19/ Haberstroh R.D., Reinders R.D., "Conductton-sheet model for natural convection through a density-stratified interface," Int. J. Heat Mass Transfer. 17 (1974) p.307

/10/Werle H., "Experimental investigation of heat transfer between two horizontal liquid layers with gas injection", Proc. Fourth Post Accident Heat Removal Information Exchange, Ispra 1978, Europ. Appl. Res. Reports Vol.1. Nr.6 (1979) p.164

/11/M. Reimann, S. Stiefel, "Hydrodynamische und thermische Modelle zur Wechselwirkung einer Kernschmelze mit "Beton", in Projekt Nukleare Sicherheit, Jahresbericht 1980, KfK 2950 (1981) 
Table 1: Material properties of silicone oil AK5 /8/

Density $\left(\mathrm{g} / \mathrm{cm}^{3}\right)$

Coeff. vol. expansion $\left(1 /{ }^{\circ} \mathrm{C}\right)$

Kinematic viscosity $\left(\mathrm{cm}^{2} / \mathrm{s}\right)$

$$
0.91\left(25^{\circ} \mathrm{C}\right)
$$

$1.05-3^{*}\left(0-150^{\circ} \mathrm{C}\right)$

$.069 \quad\left(10^{\circ} \mathrm{C}\right)$

$.046\left(30^{\circ} \mathrm{C}\right)$

$.033\left(50^{\circ} \mathrm{C}\right)$

Thermal c'onductivity $\left(\mathrm{W} / \mathrm{cm}^{\circ} \mathrm{C}\right)$

$1.17-3$

specific heat $\left(\mathrm{J} / \mathrm{g}^{\circ} \mathrm{C}\right)$

1.42

surface tension (dyn/cm)

19.7

$.21-22$ (own measurement)

Interfacial tension

38

(own measurement)

(demineralized water)

* $1.05-3$ means $1.05 \cdot 10^{-3}$ 


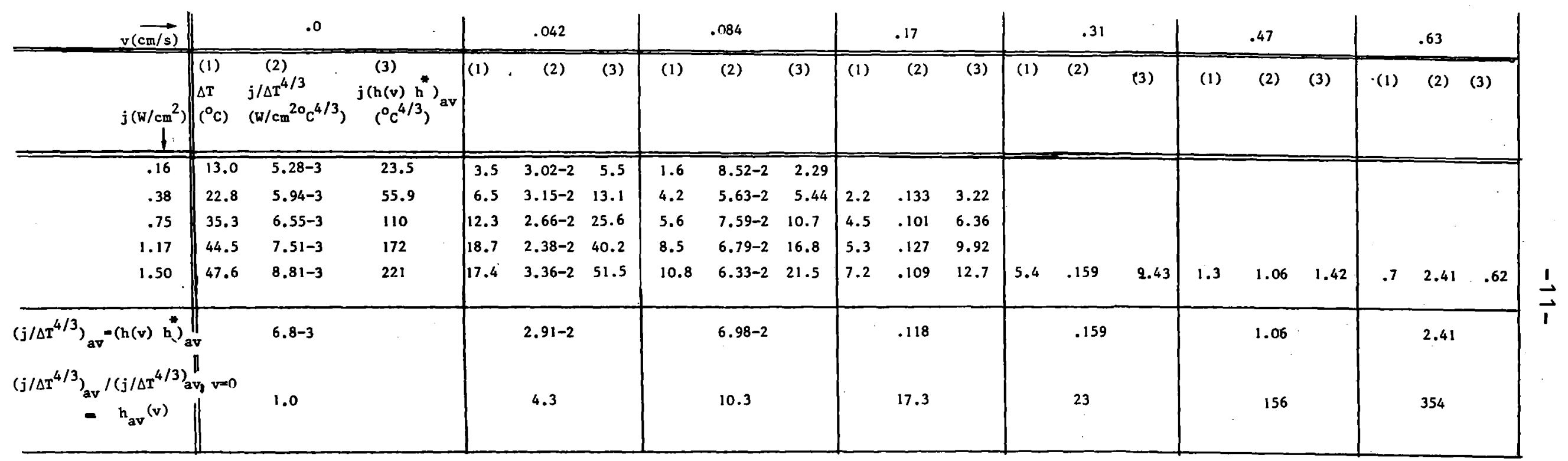

Tab. 2 Oil over water $(78 / 6)$, Air flow

Experimental set-up. Fig.2

$\mathrm{T}_{\text {low }}$ average of TC 5,$6 ; \mathrm{T}_{\text {high }}$ from TC2 


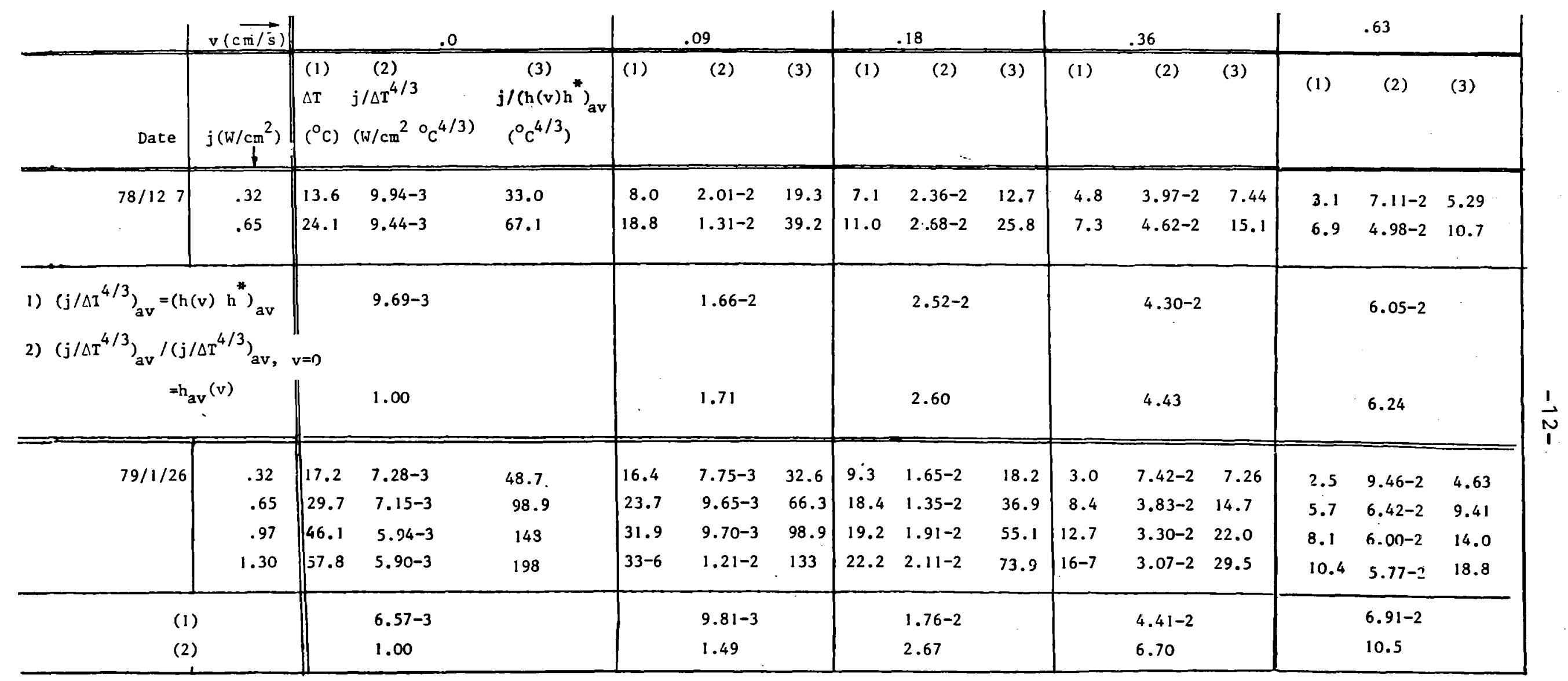

Table 3: Oil over Wood metal $(78 / 12 / 7,79 / 1 / 26)$, Nitrogen flow Experimental set-up Fig.3

$\mathrm{T}_{\text {low }}$ average of TC 4,5,6; $\mathrm{T}_{\text {high }}$ extrapolated from $\mathrm{TC} 1,2$ for position of interface 


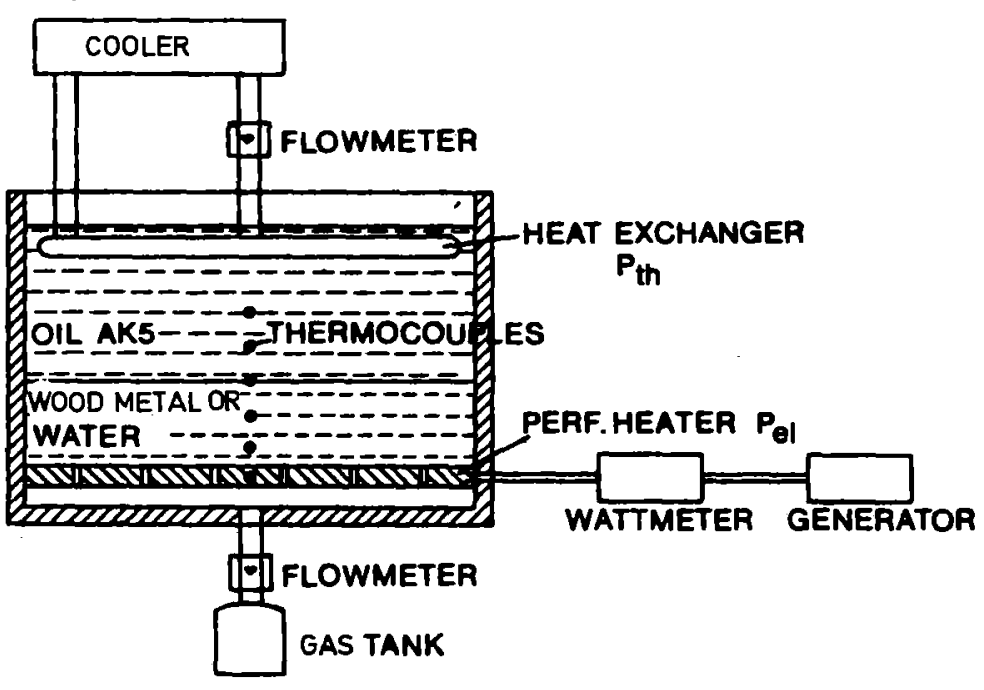

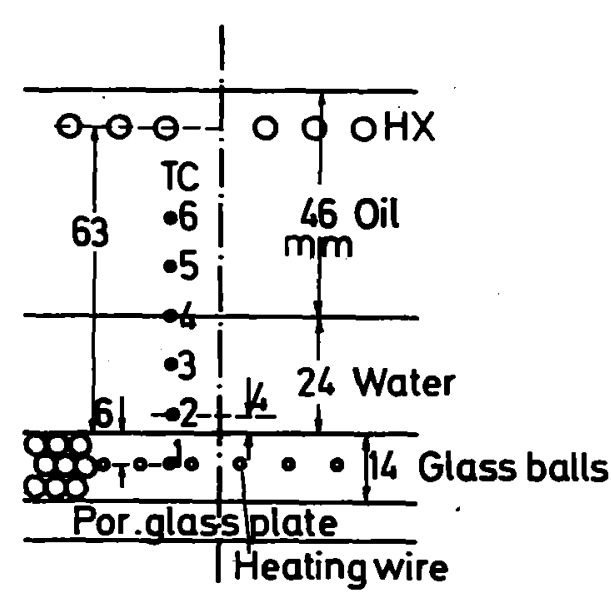

Fig. 2 ARRANGEMENT FOR OIL OVER WATER

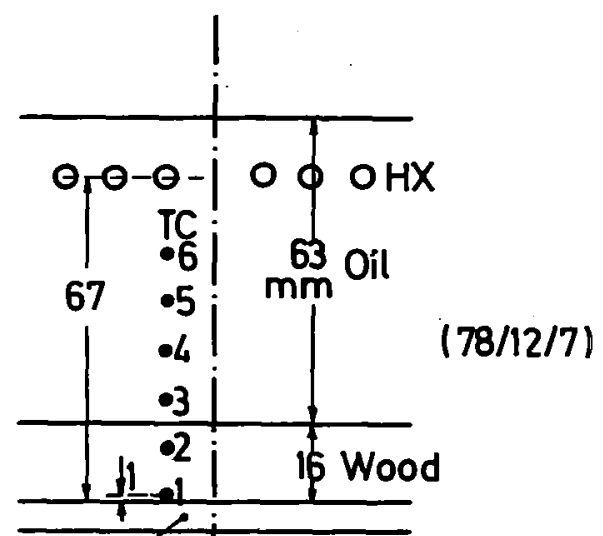

Perf.héat. lcopper plate

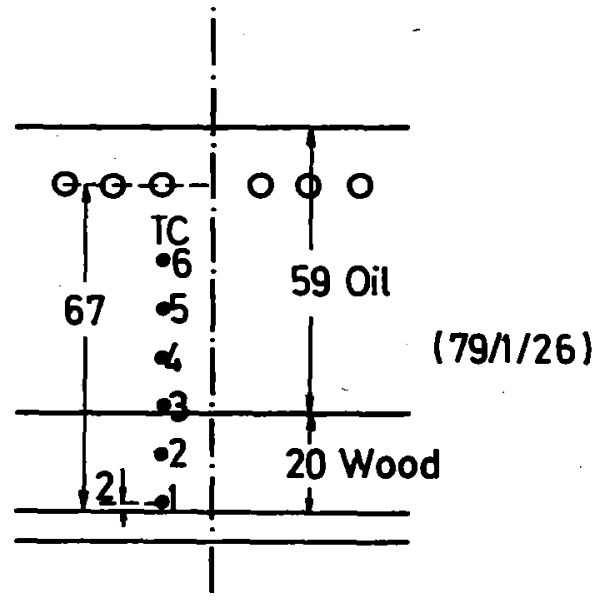

Fig. 3 ARRANGEMENT FOR OIL OVER WOOD METAL

Fig. 1 EXPERIMENTAL APPARATUS (Schematic) 


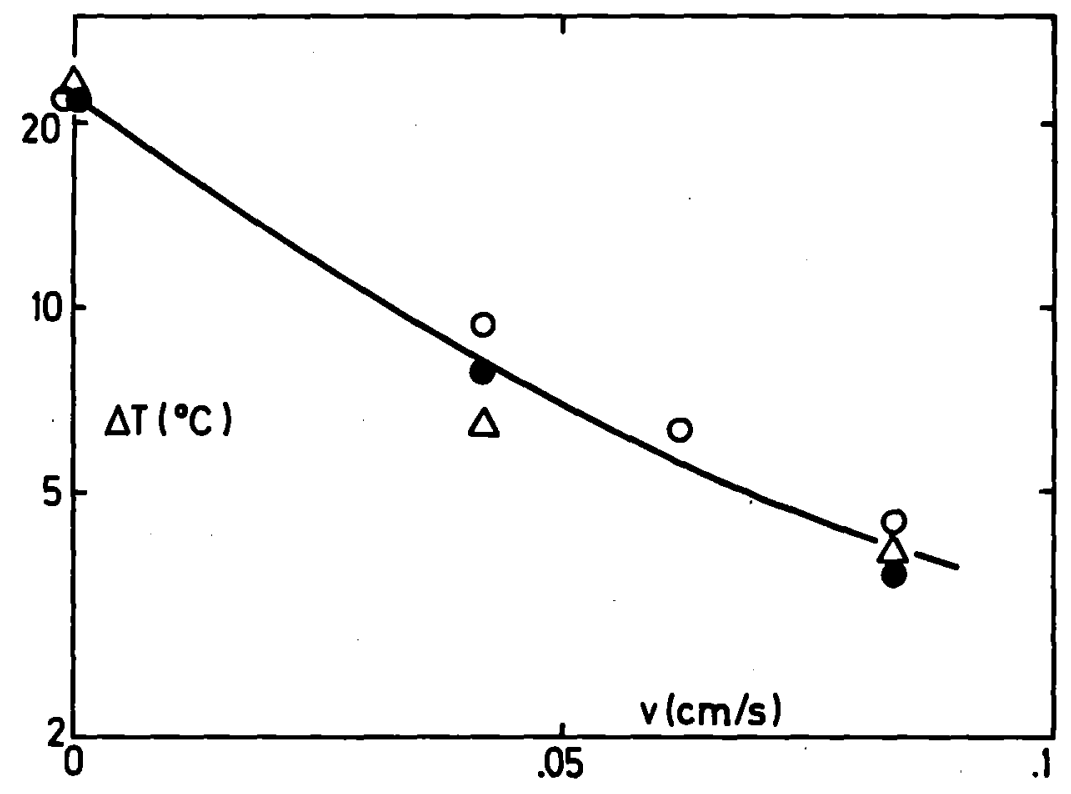

- Porous glas plate, bubble diameter $1 \mathrm{~mm}$

- $10 \mathrm{~mm}$ thick layer of $3 \mathrm{~mm}$ diameter steel spheres above porous glass plate, bubble diameter $4 \mathrm{~mm}$

$\Delta 10 \mathrm{~mm}$ thick layer of $4 \mathrm{~mm}$ diameter glass balls above porous glass plate, bubble diameter 1 - $4 \mathrm{~mm}$

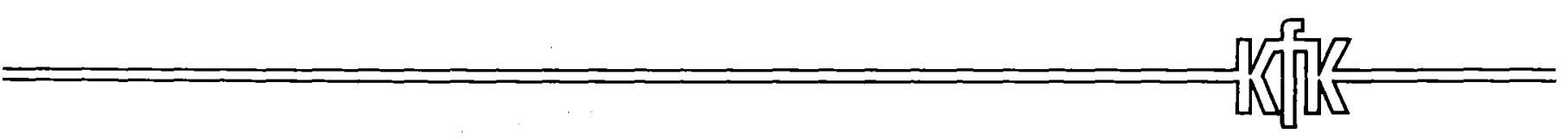

Fig. 4 DEPENDANCE OF INTERFACIAL TEMPERATURE DIFFERENCE ON BUBBLE DIAMETER FOR OIL OVER WATER $\left(j=0.38 \mathrm{~W} / \mathrm{cm}^{2}\right.$ ) 

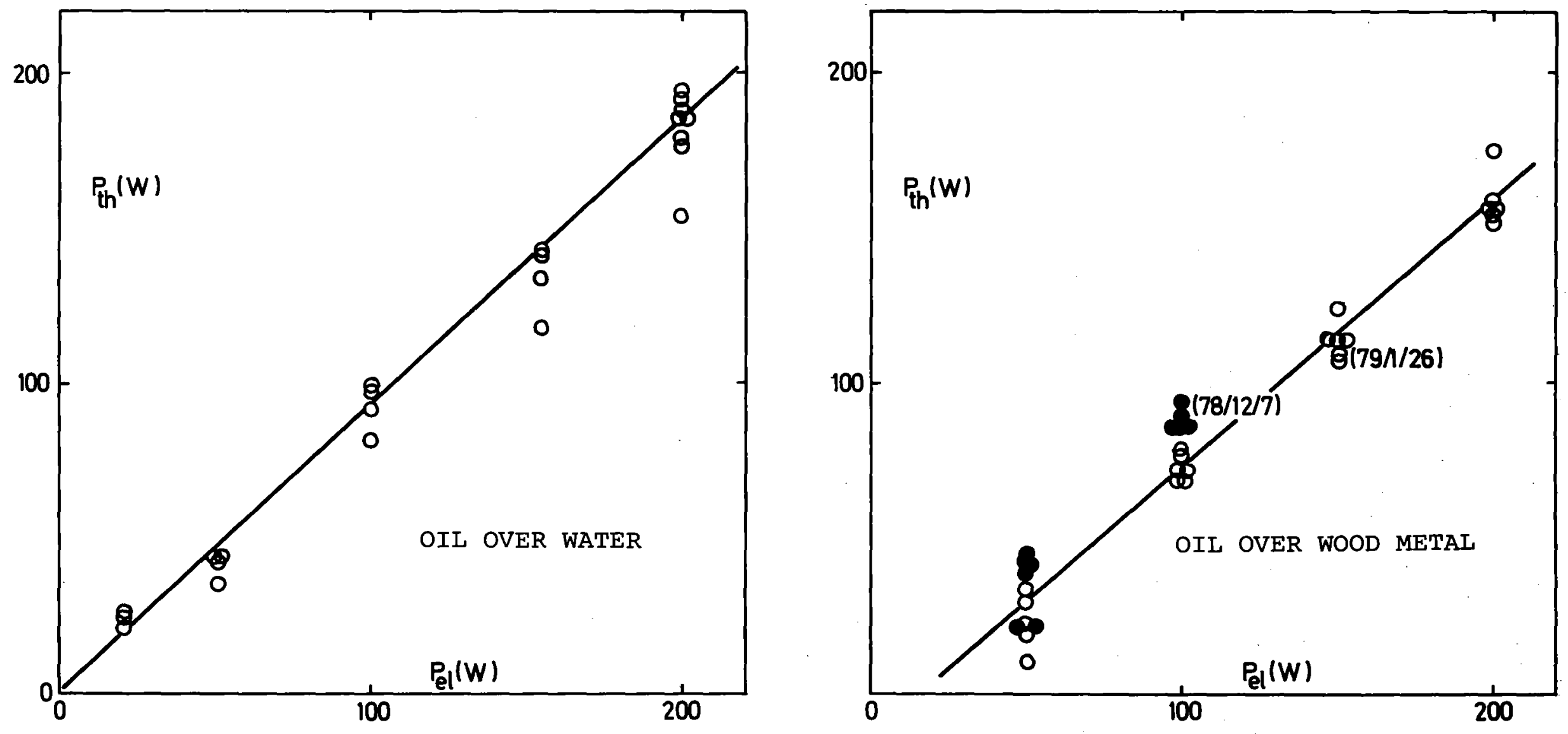

Fig. 5 COMPARISON OF ELECTRICIAL AND THERMAL POWER 

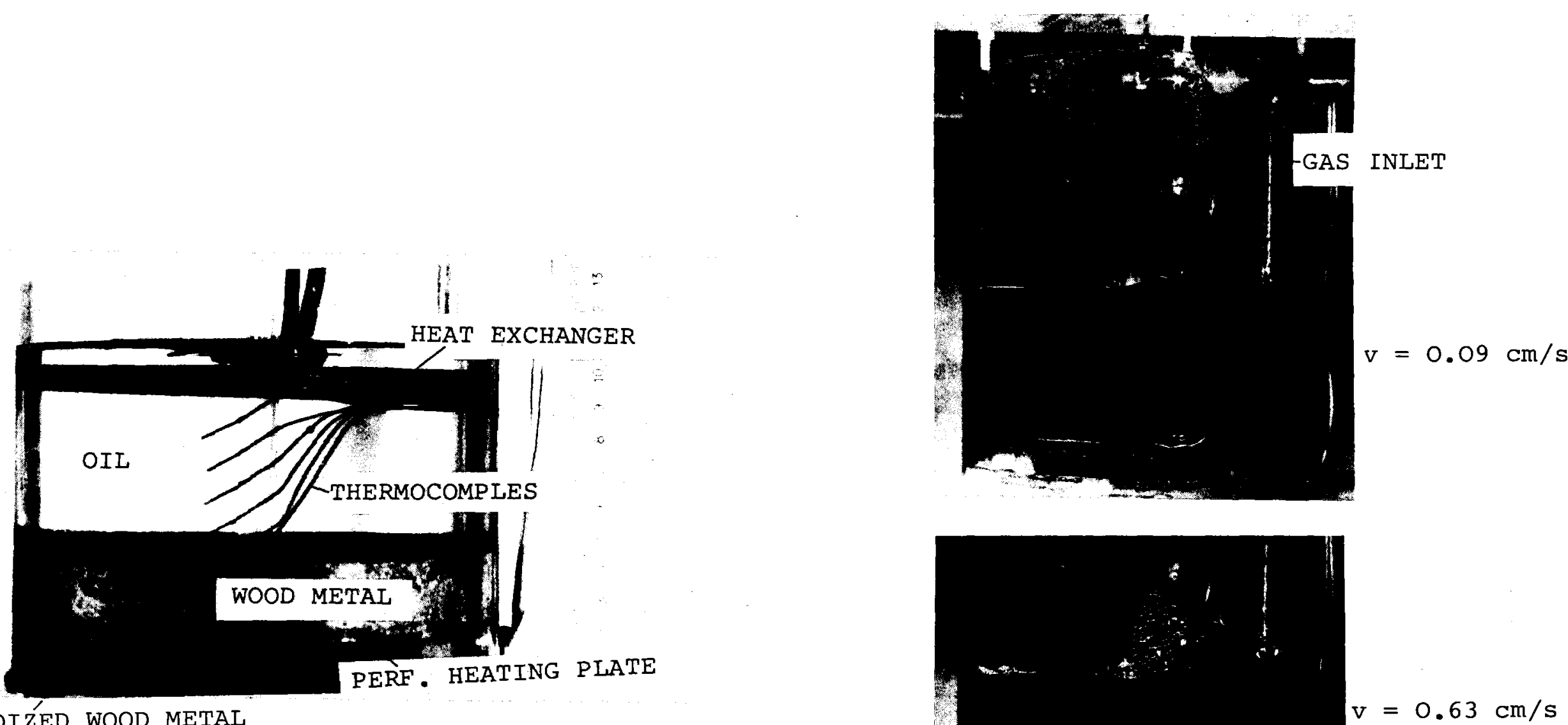
OXYDIZEED WOOD METAL

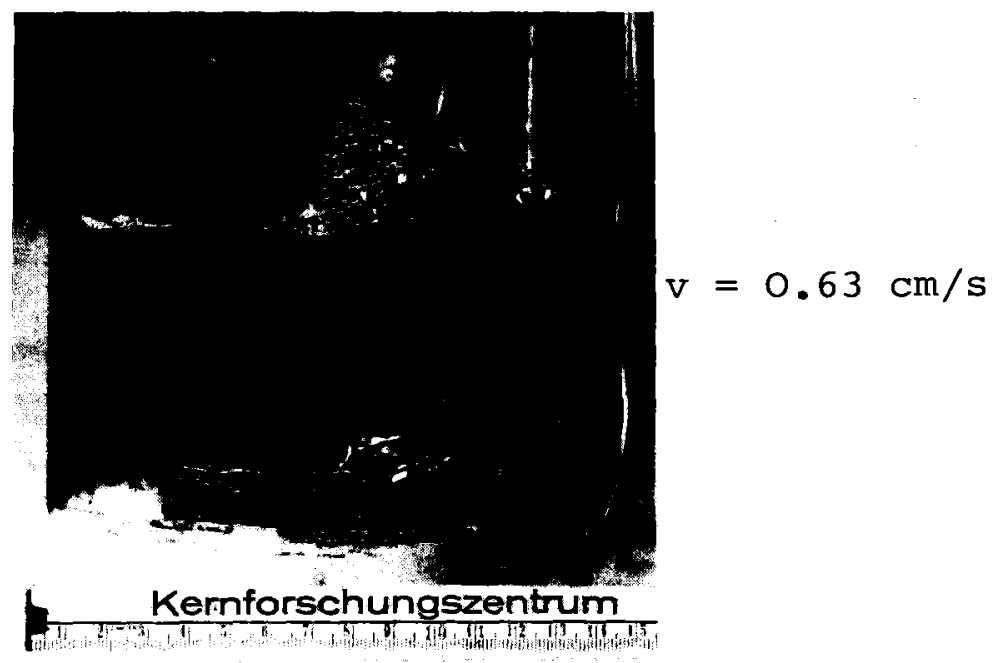



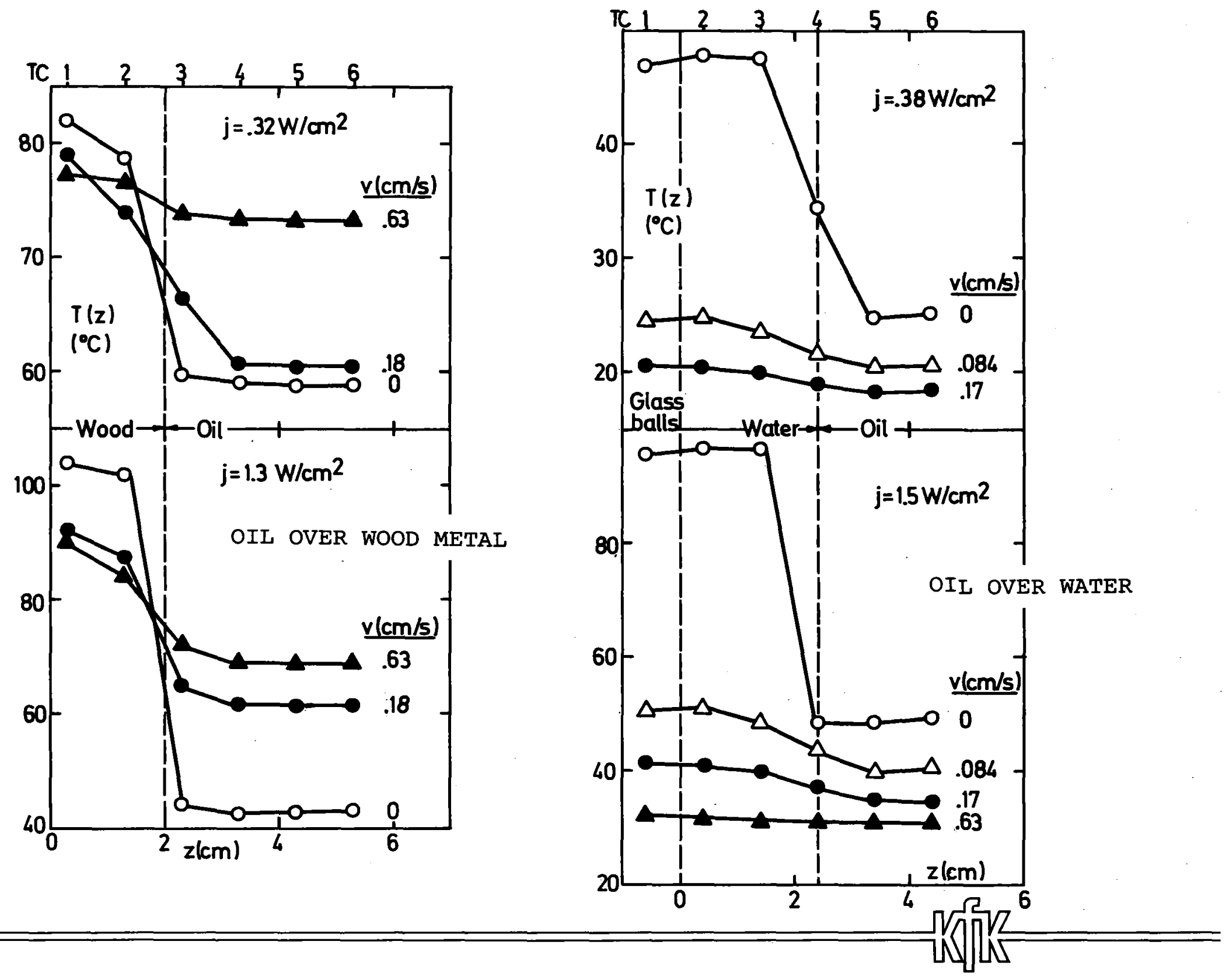

Fig. 7 AXIAL TEMPERATURE DISTRIBUTION 


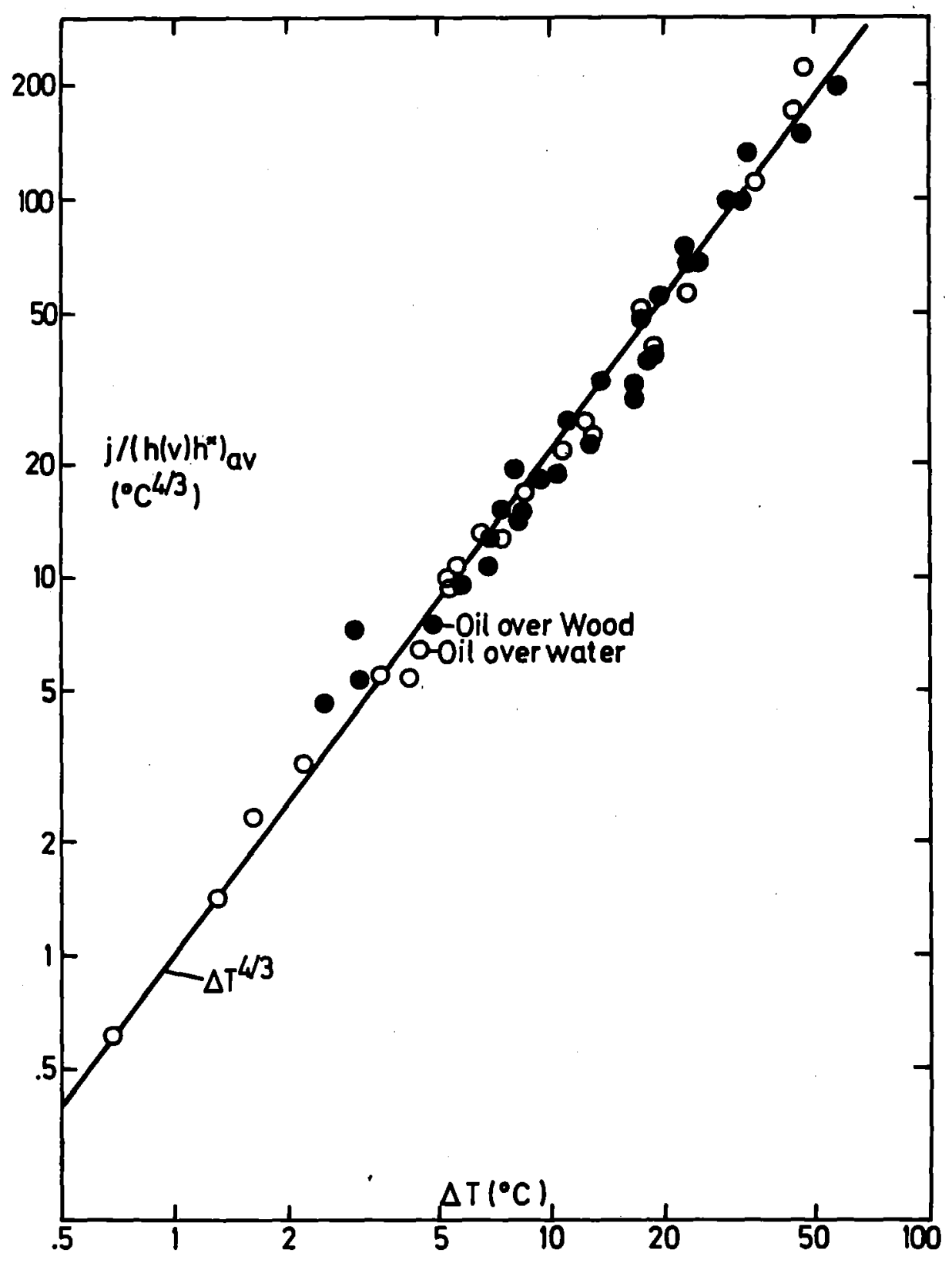

Fig. 8 DEPENDENCE OF NORMALIZED HEAT FLUX ON TEMPERATURE DIFFERENCE 


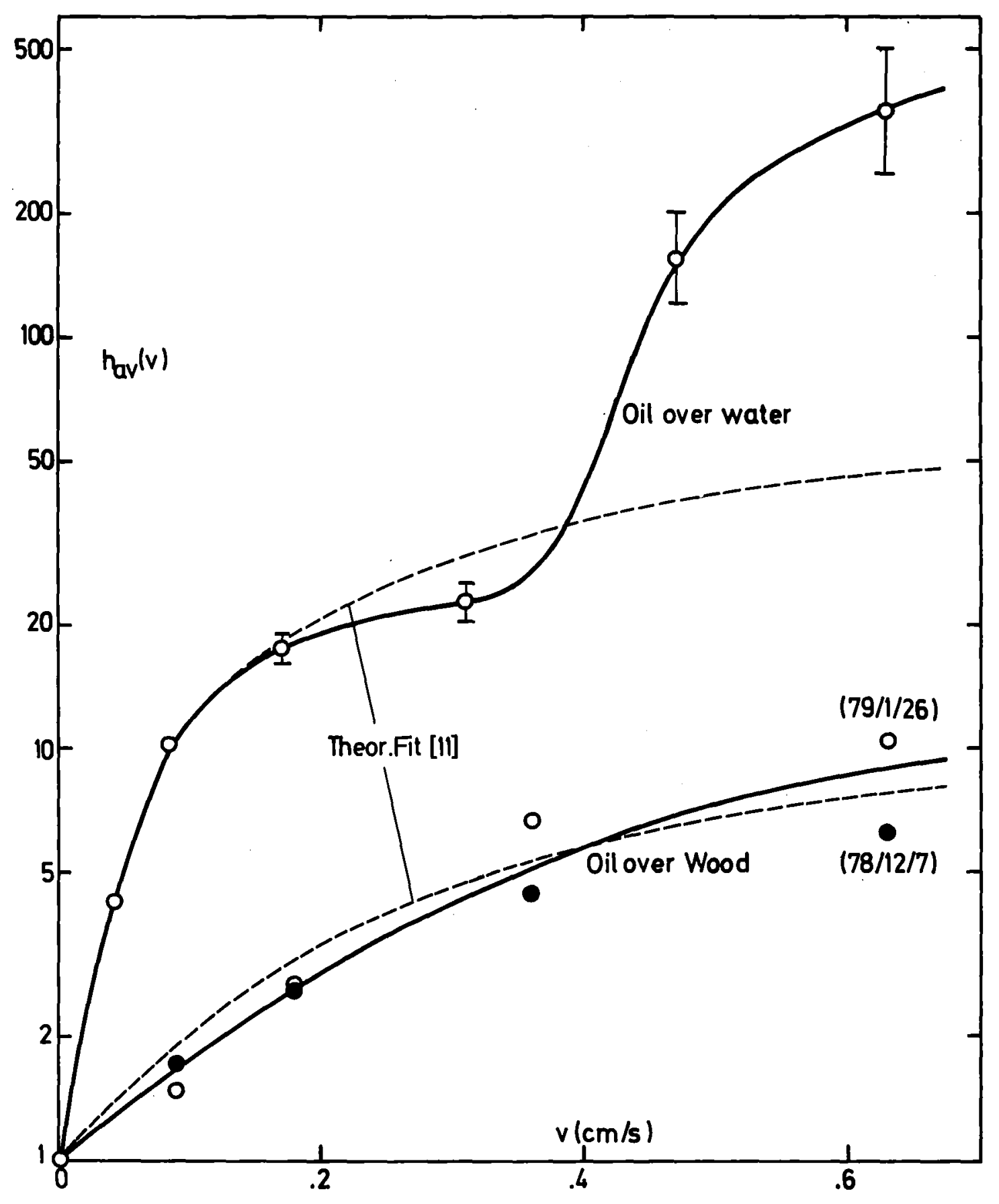

Fig. 9 HEAT TRANSFER COEFF́ICIENT AS A FUNCTION OF SUPERFICIAL GAS VELOCITY 